\title{
Repeated Mesenchymal Stem Cell Treatment after Neonatal Hypoxia-Ischemia Has Distinct Effects on Formation and Maturation of New Neurons and Oligodendrocytes Leading to Restoration of Damage, Corticospinal Motor Tract Activity, and Sensorimotor Function
}

\author{
Cindy T. J. van Velthoven, ${ }^{1,2}$ Annemieke Kavelaars, ${ }^{1,3}$ Frank van Bel, ${ }^{2}$ and Cobi J. Heijnen ${ }^{1}$ \\ ${ }^{1}$ Laboratory of Neuroimmunology and Developmental Origins of Disease, ${ }^{2}$ Department of Neonatology, University Medical Center Utrecht, 3584 EA \\ Utrecht, The Netherlands, and ${ }^{3}$ Integrative Immunology and Behavior Program, College of Agricultural, Consumer, and Environmental Sciences, and \\ College of Medicine, University of Illinois at Urbana-Champaign, Urbana, Illinois 61801
}

Birth asphyxia is a frequent cause of perinatal morbidity and mortality with limited therapeutic options. We show that a single mesenchymal stem cell treatment at $3 \mathrm{~d}$ (MSC-3) after neonatal hypoxia-ischemia (HI) in postnatal day 9 mice improved sensorimotor function and reduced lesion size. A second MSC treatment at $10 \mathrm{~d}$ after HI (MSC-3 + 10) further enhanced sensorimotor improvement and recovery of MAP2 and MBP (myelin basic protein) staining. Ipsilateral anterograde corticospinal tract tracing with biotinylated dextran amine (BDA) showed that HI reduced BDA labeling of the contralateral spinal cord. Only MSC-3+10 treatment partially restored contralateral spinal cord BDA staining, indicating enhanced axonal remodeling. MSC-3 enhanced formation of bromodeoxyuridine-positive neurons and oligodendrocytes. Interestingly, the second gift at day 10 did not further increase new cell formation, whereas only MSC-10 did. These findings indicate that increased positive effect of MSC-3+ 10 compared with MSC-3 alone is mediated via distinct pathways. We hypothesize that MSCs adapt their growth and differentiation factor production to the needs of the environment at the time of intracranial injection. Comparing the response of MSCs to in vitro culture with HI brain extracts obtained at day 10 from MSC-3- or vehicletreated animals by pathway-focused PCR array analysis revealed that 29 genes encoding secreted factors were indeed differentially regulated. We propose that the function of MSCs is dictated by adaptive specific signals provided by the damaged and regenerating brain.

\section{Introduction}

Perinatal cerebral hypoxia-ischemia (HI) remains a major cause of neonatal morbidity and mortality. Current options for treatment are limited (Volpe, 2001; Ferriero, 2004). Until recently, it was thought impossible to achieve regeneration of brain tissue after HI. However, recent research shows that transplantation of several types of stem cells, including neural stem cells, multipotent adult progenitor cells, mesenchymal stem cells (MSCs), and human umbilical cord blood cells, can have beneficial effects on ischemic brain injury (Meier et al., 2006; Yasuhara et al., 2008; Daadi et al., 2010; Lee et al., 2010; Pimentel-Coelho et al., 2010; van Velthoven et al., 2010) (for review, see Pimentel-Coelho and Mendez-Otero, 2010).

Orthotopic MSCs support hematopoietic stem cells to differentiate into mature blood cells by secretion of cytokines and growth factors. In the injured brain, transplanted MSCs are thought to im-

Received April 11, 2010; revised May 21, 2010; accepted June 8, 2010.

This work was supported by the Wilhelmina Children's Hospital Research Fund.

Correspondence should be addressed to Dr. Cobi J. Heijnen, Professor of Psychoneuroimmunology, Room KC03.068.0, University Medical Center Utrecht, Lundlaan 6, 3584 EA Utrecht, The Netherlands. E-mail: c.heijnen@ umcutrecht.nl.

DOI:10.1523/JNEUROSCI.1835-10.2010

Copyright $\odot 2010$ the authors $\quad 0270-6474 / 10 / 309603-09 \$ 15.00 / 0$ prove endogenous repair processes by release of growth and differentiation factors enhancing the local trophic milieu ( $\mathrm{Li}$ et al., 2002; Qu et al., 2007; van Velthoven et al., 2009). It has also been suggested that MSCs can differentiate into neurons and oligodendrocytes and thereby contribute to repair of the injured brain (Mezey et al., 2000; Shen et al., 2007). Restoration of function and regeneration of lost tissue not only requires neurogenesis but also restoration of functional networks via axonal sprouting and synaptogenesis (Carmichael, 2006; Zhang and Chopp, 2009).

Recently, we demonstrated that MSC transplantation after neonatal HI decreased gray and white matter loss and enhanced neurogenesis and oligodendrogenesis (van Velthoven et al., 2010). In addition, we and others have shown that transplantation of bone marrow-derived MSCs markedly improves functional outcome after neonatal hypoxia ischemia (Yasuhara et al., 2006, 2008; Lee et al., 2010; van Velthoven et al., 2010). Previously, we treated neonatal mice with MSCs at $3 \mathrm{~d}$ after HI. Although sensorimotor function markedly improved when measured at 10 and $21 \mathrm{~d}$ after HI, functional impairment still increased over time in both vehicle (VEH)- and MSC-treated HI mice. This led us to investigate here whether a second injection with MSCs at $10 \mathrm{~d}$ after HI attenuates the additional loss of sensorimotor function over time. 
The corticospinal tract (CST) represents the primary transmission tract for brain-controlled voluntary movement (Fromm and Evarts, 1982) and consists of axons from pyramidal neurons originating in the motor cortex extending to the contralateral spinal cord. The injury in our model of neonatal HI brain damage causes contralateral sensorimotor impairment as attested by an increased preference for ipsilateral forepaw use when rearing (Chang et al., 2005; van der Kooij et al., 2010). We hypothesized that HI caused motor impairment by damaging long tracts as suggested by Weidner et al. (2001) and that CST remodeling contributes to sensorimotor improvement after MSC treatment in our model of neonatal HI brain damage. We also analyzed the effect of MSC treatment at 3 or 3 and $10 \mathrm{~d}$ after $\mathrm{HI}$ on cerebral cell proliferation, formation of new neurons and oligodendrocytes, and gray and white matter loss. In addition, we determined the effect of $\mathrm{HI}$ brain extract on growth and differentiation factor expression by MSCs.

\section{Materials and Methods}

MSCs. Bone marrow from femur and tibia of 6- to 8-week-old C57BL/6$\mathrm{Tg}$ (UBC-GFP)30Scha/J mice (The Jackson Laboratory) was cultured in DMEM $/ 15 \%$ fetal bovine serum as described previously (van Velthoven et al., 2010). Cells were negative for myeloid and hematopoietic cell lineage-specific antigens and positive for Sca-1, CD90, CD29, CD44, and MHC class I (van Velthoven et al., 2010).

Animals. Experiments were performed according to international guidelines and approved by the University Medical Center Utrecht experimental animal committee. At postnatal day 9 (P9), C57BL/6J mice underwent $\mathrm{HI}$ by right common carotid artery occlusion under isoflurane anesthesia [ $3 \%$ induction, $1 \%$ maintenance in $\left.\mathrm{O}_{2}: \mathrm{N}_{2} \mathrm{O}(1: 1)\right]$ followed by 45 min exposure to $10 \%$ oxygen in nitrogen (Nijboer et al., 2008). This procedure induced a lesion involving hippocampus, neocortex, and striatum (van der Kooij et al., 2010). Sham controls underwent anesthesia and incision only. Pups from at least five different litters were used in each experimental group, and pups of each litter were randomly assigned to all experimental groups, taking gender into account in a way that both genders were equally distributed among experimental groups. Data were obtained in at least two independent experiments. Mortality $(\sim 10 \%)$ only occurred during or immediately after $\mathrm{HI}$, and there were no gender differences in mortality. All analyses were performed in a blinded set-up.

A total of 100,000 MSCs in $2 \mu$ l of PBS or vehicle were infused into the ipsilateral hemisphere at $2 \mathrm{~mm}$ caudal to bregma, $2 \mathrm{~mm}$ right from midline, and $2 \mathrm{~mm}$ below dural surface under isoflurane anesthesia.

To evaluate cell proliferation/survival, mice received bromodeoxyuridine (BrdU) (50 mg/kg, i.p.; Sigma-Aldrich) at days 3, 4, and 5, and ethynyldeoxyuridine (EdU) $(50 \mathrm{mg} / \mathrm{kg}$, i.p.; Invitrogen) at days 10,11 , and 12 after HI (Fig. 1). We confirmed that BrdU and EdU are equally sensitive in labeling proliferating cells (data not shown) (Chehrehasa et al., 2009).

At $21 \mathrm{~d}$ after $\mathrm{HI}$, animals received an injection of $1 \mu \mathrm{l}$ of $10 \%$ biotinylated dextran amine (BDA) (10,000d; Invitrogen) in PBS into the forelimb sensorimotor cortex ipsilateral to the ischemic hemisphere $(0.5 \mathrm{~mm}$ anterior, $2.25 \mathrm{~mm}$ lateral, $0.55 \mathrm{~mm}$ depth relative to bregma).

Animals were killed at day 21 or day 28 after $\mathrm{HI}$ with pentobarbital and perfused with $4 \%$ paraformaldehyde in PBS.

Functional outcome. The cylinder rearing test was used to assess forelimb use asymmetry as described previously (van Velthoven et al., 2010). The weight-bearing forepaw(s) to contact the wall during a full rear was recorded as left (impaired), right (nonimpaired), or both. Paw preference was calculated as follows: ((nonimpaired - impaired)/ (nonimpaired forepaw + impaired forepaw + both $)) \times 100 \%$ (van der Kooij et al., 2010; van Velthoven et al., 2010). Interobserver reliability was 0.87 at 21 or $28 \mathrm{~d}$ after $\mathrm{HI}$ and 0.76 at $10 \mathrm{~d}$ after $\mathrm{HI}$.

Motor function was also analyzed using a rotarod treadmill (Stoelting) at constant speed $(10 \mathrm{rpm})$. The mean time (maximum, $3 \mathrm{~min}$ ) each animal stayed on the rotarod was determined in five consecutive trials with 10 min intervals.

Histology and immunohistochemistry. Coronal paraffin sections $(6 \mu \mathrm{m})$ were incubated with mouse anti-myelin basic protein (MBP) (Sternberger Monoclonals), mouse anti-microtubule-associated protein (MAP2) (Sigma-Aldrich), rabbit anti-GAP43, or rabbit anti-synaptophysin (Abcam), and binding was visualized with a Vectastain $\mathrm{ABC}$ kit (Vector Laboratories). Brain damage was analyzed at a location equivalent to $-1.58 \mathrm{~mm}$ from bregma in adult mice by outlining both hemispheres on full section images using ImageJ software (W. S. Rasband, ImageJ, National Institutes of Health, Bethesda, MD; http://rsb.info.nih.gov/ij/; 1997-2009). Ipsilateral MAP2 and MBP area loss were calculated as described previously (Nijboer et al., 2008).

For cell proliferation and differentiation analysis, sections were incubated with biotinylated sheep anti-BrdU (Abcam) and mouse anti-NeuN or rabbit anti-Olig2 (Millipore). Visualization was done with Alexa Fluor 594-conjugated streptavidin and Alexa Fluor 488-anti-IgG (Invitrogen). EdU incorporation was detected by incubating sections in $100 \mathrm{~mm}$ Tris containing $0.5 \mathrm{mM} \mathrm{CuSO}_{4}, 50 \mathrm{~mm}$ ascorbic acid, and $10 \mu \mathrm{M}$ Alexa Fluor 594-azide (Invitrogen). BrdU-positive or EdU-positive cells were counted in hippocampus and six cortical high magnification fields in three sections per brain. BrdU/NeuN, BrdU/Olig2, EdU/NeuN, and EdU/Olig2 double-positive cells were counted in hippocampus and six cortical high-magnification fields $\left(0.18 \mathrm{~mm}^{2}\right.$ per field $)$ in three sections per animal. For BDA tracing, cervical spinal cord sections $(15 \mu \mathrm{m})$ were incubated with Vectastain $\mathrm{ABC}$ kit at $4^{\circ} \mathrm{C}$ for $24 \mathrm{~h}$ and visualized with DAB-nickel (Sigma-Aldrich). BDA intensity in the dorsal funiculus of the spinal cord was quantified using ImageJ software.

MSC gene expression profile after culture with ischemic brain extracts. To assess the effect of signals provided by the ischemic brain on MSC gene expression, MSCs were cultured in vitro with extracts from the brain as described previously with minor modifications (Qu et al., 2007). Mice were treated at $3 \mathrm{~d}$ after $\mathrm{HI}$ with MSCs or vehicle and brains were collected at $10 \mathrm{~d}$ after HI. A standardized section of the ischemic hemisphere, centered at the HI lesion (bregma, $-2 \sim 0 \mathrm{~mm}$ ) was obtained by dissection on ice. Brain sections were homogenized at $150 \mathrm{mg} / \mathrm{ml}$ in knock-out DMEM (Invitrogen), clarified by centrifugation for $10 \mathrm{~min}$ at $10,000 \times g$ at $4^{\circ} \mathrm{C}$. Protein concentration was determined using a protein assay (Bio-Rad) with BSA as standard and stored at $-80^{\circ} \mathrm{C}$ until use. A total of $1 \times 10^{6}$ MSCs per well was seeded in six-well plates in complete MSC medium. After $24 \mathrm{~h}$, culture medium was replaced with knock-out DMEM containing brain extract (final concentration, $1 \mathrm{mg}$ protein $/ \mathrm{ml}$ ) from $\mathrm{HI}+$ vehicle-treated or $\mathrm{HI}+\mathrm{MSC}$-treated ischemic brain extract ( $n=4$ per condition). After $72 \mathrm{~h}$ in culture, total RNA was isolated from the MSCs using the RNeasy mini kit (QIAGEN) and transcribed to cDNA using the $\mathrm{RT}^{2}$ first-stand synthesis kit (SABiosciences). cDNAs from each experimental condition were pooled and PCR array analysis was performed according to manufacturer's protocol with the $\mathrm{RT}^{2}$ RealTime SYBR Green PCR Master Mix on the Bio-Rad iQ5. Expression of 200 genes was analyzed using the following $\mathrm{RT}^{2}$ profiler PCR arrays: Growth Factors (PAMM-041), Neurogenesis and Neural Stem Cell (PAMM-404), and Neurotrophin and Receptor (PAMM-031) (SABiosciences). Data were normalized using multiple housekeeping genes and 
analyzed by comparing $2^{-\Delta \mathrm{Ct}}$ of the normalized data. Fold changes were calculated relative to MSCs cultured in brain extracts from HI animals treated with vehicle at $3 \mathrm{~d}$ after $\mathrm{HI}$ and killed at $10 \mathrm{~d}$ after HI. The results were confirmed by quantitative reverse transcription (qRT)-PCR analysis on the individual samples for four genes that showed the strongest upregulation and three with the strongest downregulation.

Culture supernatants were collected after $72 \mathrm{~h}$ in culture and analyzed for interleukin-1 $\beta$ (IL-1 $\beta$ ), IL-6, and IL-10 production with a Luminex Multiplex kit according to manufacturer's instructions (fluorokine MAP multiplex mouse cytokine panel; R\&D Systems).

Statistical analysis. All data are expressed as means \pm SEM. Functional outcome measured with cylinder rearing test and rotarod were analyzed using two-way ANOVA with Fisher's least significant difference posttests. A value of $p<0.05$ was considered statistically significant. Histological measures were analyzed using two-way ANOVA with Bonferroni's posttests. A value of $p<0.05$ was considered statistically significant. The relationship between BDA staining and impairment in the cylinder rearing test was analyzed by Pearson's correlation. Data were analyzed for the presence of outliers using Grubbs' outlier test. This resulted in removal of one outlier in the MSC $3+10$ group with extremely high BDA staining from the analysis of this parameter. For all other parameters, we did not detect outliers. qRT-PCR data were compared by Student's $t$ test, and for these analyses $p<0.001$ was considered statistically significant.

\section{Results}

\section{Effect of MSC treatment after HI on sensorimotor function}

Mice underwent $\mathrm{HI}$ on $\mathrm{P} 9$ and were treated with MSCs or vehicle at 3 and $10 \mathrm{~d}$ (MSC-3+10 or VEH) after HI. A third group of mice was treated with MSCs at $3 \mathrm{~d}$ and vehicle at $10 \mathrm{~d}$ after $\mathrm{HI}$ (MSC-3). In the cylinder rearing test performed at 10, 21, and $28 \mathrm{~d}$ after HI, VEH HI animals showed a marked increase in functional impairment over time (Fig. 2A). MSC-3 treatment significantly improved performance in the cylinder rearing test at all time points tested. However, in line with our previous results (van Velthoven et al., 2010), there was still an increase in paw preference over time, indicating that impairment increased over time. MSC-3+10 treatment reduced paw preference when compared with vehicle- and single MSC-treated $\mathrm{HI}$ animals at 21 and $28 \mathrm{~d}$ after HI (at $28 \mathrm{~d}$ : MSC-3+10 vs VEH, $46 \pm 6 \%$ improvement; MSC-3+10 vs MSC-3, $28 \pm 4 \%$ improvement; $p<0.05)$. Notably, MSC-3+10 treatment prevented the increase in sensorimotor impairment over time (Fig. $2 A$ ).

Performance on the rotarod at 21 and $28 \mathrm{~d}$ after HI was impaired. MSC-3 treatment improved rotarod performance at 21 and $28 \mathrm{~d}$ after HI. Moreover, at $28 \mathrm{~d}$ after HI MSC-3+ 10, animals performed significantly better than MSC-3 animals (Fig. $2 \mathrm{~B}$ ).

\section{Effect of MSC treatment on cell proliferation/survival}

To determine whether improved motor function after MSC treatment was associated with increased cerebral cell proliferation/survival, animals were treated with BrdU after the first MSC treatment and, to be able to discriminate between proliferation after the first and the second injection, with EdU after the second MSC treatment. BrdU was administered at days 3, 4, and 5 after HI (Fig. 1). MSC-3 treatment significantly increased the number of BrdU-positive cells in the hippocampus as determined at $21 \mathrm{~d}$ after the insult. At $28 \mathrm{~d}$ after HI, the number of BrdU-positive cells in the hippocampus did no longer differ between VEH- and MSC-3-treated animals (Fig. 3A). In the cortex, MSC-3 treatment significantly increased the number of BrdU-positive cells at both 21 and $28 \mathrm{~d}$ after HI compared with VEH HI animals (Fig. $3 B)$. Notably, MSC-3+10 treatment did not further increase the number of BrdU-positive cells as determined at 21 or $28 \mathrm{~d}$ after HI (Fig. $3 A, B$ ). The selective effect of the second MSC treatment
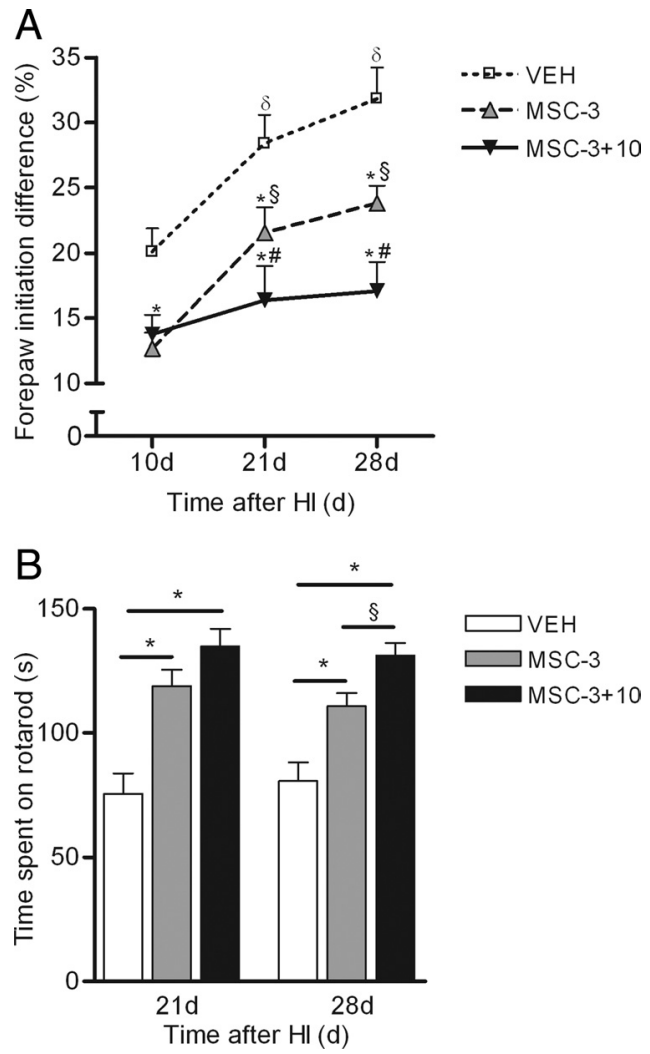

Figure 2. Effect of MSC treatment at 3 and $10 \mathrm{~d}$ after HI on functional outcome. Mice received MSCS or VEH at 3 and $10 \mathrm{~d}$ after $\mathrm{HI}$. $\boldsymbol{A}$, Paw preference in the cylinder rearing test was determined at 10,21 , and $28 \mathrm{~d}$ after the insult. $\boldsymbol{B}$, Performance on the rotarod at 21 and $28 \mathrm{~d}$ after HI. Data represent mean \pm SEM. VEH, $n=12$; MSC -3 and MSC $-3+10, n=14 .{ }^{\delta} p<0.01$ versus VEH at $10 \mathrm{~d} ;{ }^{\S} p<0.01$ versus MSC -3 at $10 \mathrm{~d} ;{ }^{*} p<0.01$ versus VEH at same time point; ${ }^{\#} p<0.01$ versus MSC-3 at same time point.

on proliferation/survival was determined after EdU injection on days 10-12 after HI (Fig. 1). Interestingly, the data demonstrated that the second MSC injection at $10 \mathrm{~d}$ after HI did not have any effect on the number of EdU-positive cells in hippocampus and cortex at 21 and $28 \mathrm{~d}$ after $\mathrm{HI}$ (Fig. 3C,D). We did not observe any effect of MSC treatment on the number of BrdU- or EdU-positive cells in the contralateral hemisphere. BrdU-positive cell number was very low in the subventricular zone at $28 \mathrm{~d}$ after $\mathrm{HI}$ and was therefore not quantified (data not shown).

We determined whether the lack of effect of the second MSC injection at $10 \mathrm{~d}$ after $\mathrm{HI}$ on brain cell proliferation was attributable to the previous injection at $3 \mathrm{~d}$ after HI. Mice were treated with a single injection of MSCs at $10 \mathrm{~d}$ (MSC-10) after HI and with EdU at 10, 11, and $12 \mathrm{~d}$ after HI. Treatment with MSCs once only at $10 \mathrm{~d}$ after $\mathrm{HI}$, significantly increased the number of hippocampal EdU-positive cells (VEH, $27.4 \pm 5.9$, vs MSC-10, $50.1 \pm 4.9 ; p<0.05)$ and of cortical EdU-positive cells (VEH, $57.8 \pm 5.7$, vs MSC-10, $87.8 \pm 8.4 ; p<0.05)$ at $21 \mathrm{~d}$ after the insult. These data show that we could reliably detect cell proliferation/survival using in vivo EdU labeling and indicate that the first MSC treatment at $3 \mathrm{~d}$ after $\mathrm{HI}$ altered the response to the second treatment so that endogenous cell proliferation/survival was no longer stimulated.

\section{Effect of MSC treatment on differentiation of recently divided cells}

To determine whether the second treatment with MSCs enhanced differentiation/survival of cells that proliferated after the first treat- 

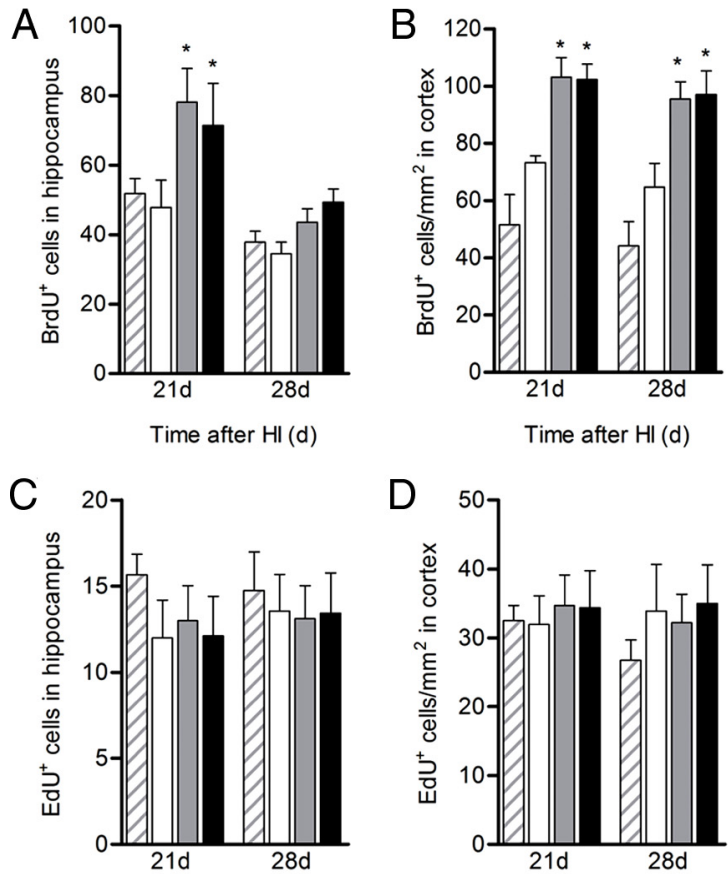

Time after $\mathrm{HI}(\mathrm{d})$

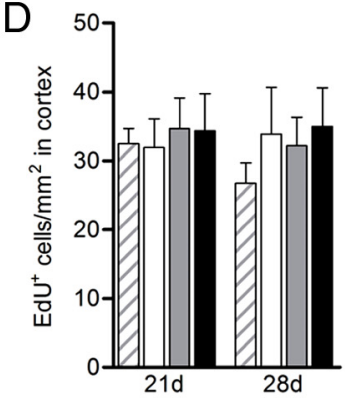

Time after $\mathrm{HI}(\mathrm{d})$
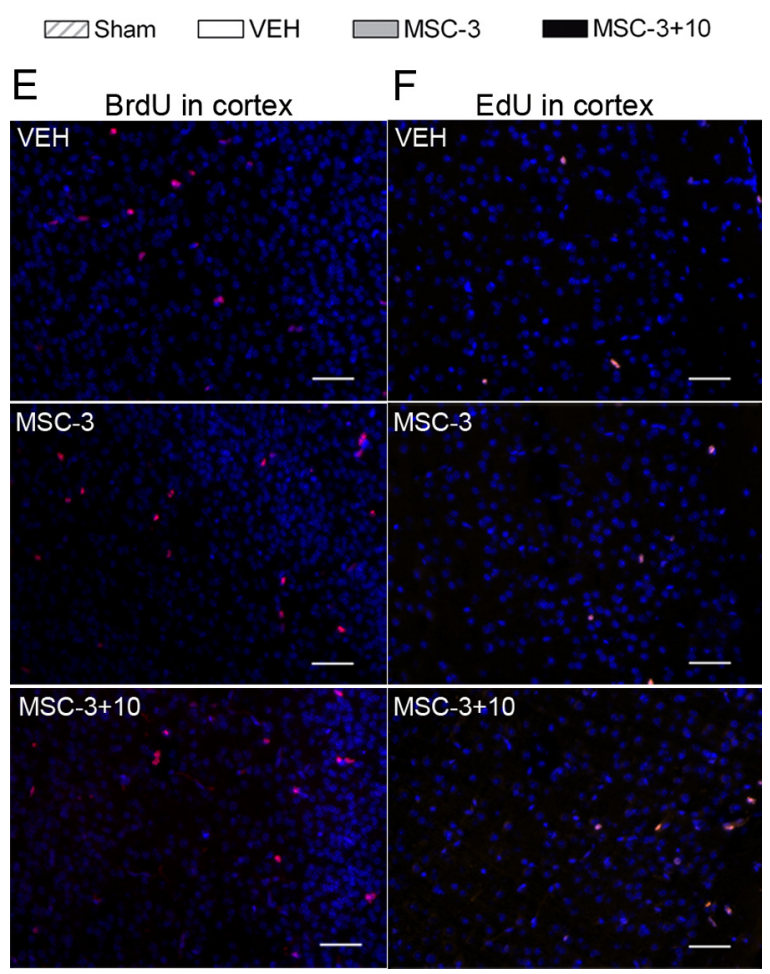

Figure 3. Cell proliferation after MSC treatment. To label proliferating cells after the first injection of MSCs at day 3 after $\mathrm{HI}$, BrdU was injected daily from 3 to $5 \mathrm{~d}$ after $\mathrm{HI}$. $\boldsymbol{A}, \boldsymbol{B}$, The number of $\mathrm{BrdU}^{+}$cells in ipsilateral hippocampus $(\boldsymbol{A})$ and cortex $(\boldsymbol{B})$ were counted. Cell proliferation after the second injection of MSCs at day 10 was analyzed after daily EdU injection from 10 to $12 \mathrm{~d}$ after HI. $\boldsymbol{C}, \boldsymbol{D}, \mathrm{EdU}^{+}$cells were counted in the hippocampus $(\boldsymbol{C})$ and cortex (D). Data represent mean number of positive cells \pm SEM. Sham controls, $n=8 ; \mathrm{VEH}, n=12 ; \mathrm{MSC}-3$ and MSC $-3+10, n=14 .{ }^{*} p<0.05 . \boldsymbol{E}$ and $\boldsymbol{F}$ display representative examples of $\operatorname{BrdU}(\boldsymbol{E})$ and $\operatorname{Edu}(\boldsymbol{F})$ staining in cortex at $28 \mathrm{~d}$ after HI of VEH, MSC-3, or MSC-3 + 10 treatment animals. Scale bars, $50 \mu \mathrm{m}$.

ment toward neurons or oligodendrocytes, we performed double immunohistochemical analysis. MSC-3 treatment increased the percentage of $\mathrm{BrdU}^{+} / \mathrm{NeuN}^{+}$cells (Fig. $4 A, B$ ) and $\mathrm{BrdU}^{+} / \mathrm{Olig}{ }^{+}$ cells (Fig. $4 C, D$ ) in hippocampus and cortex at both 21 and $28 \mathrm{~d}$ after
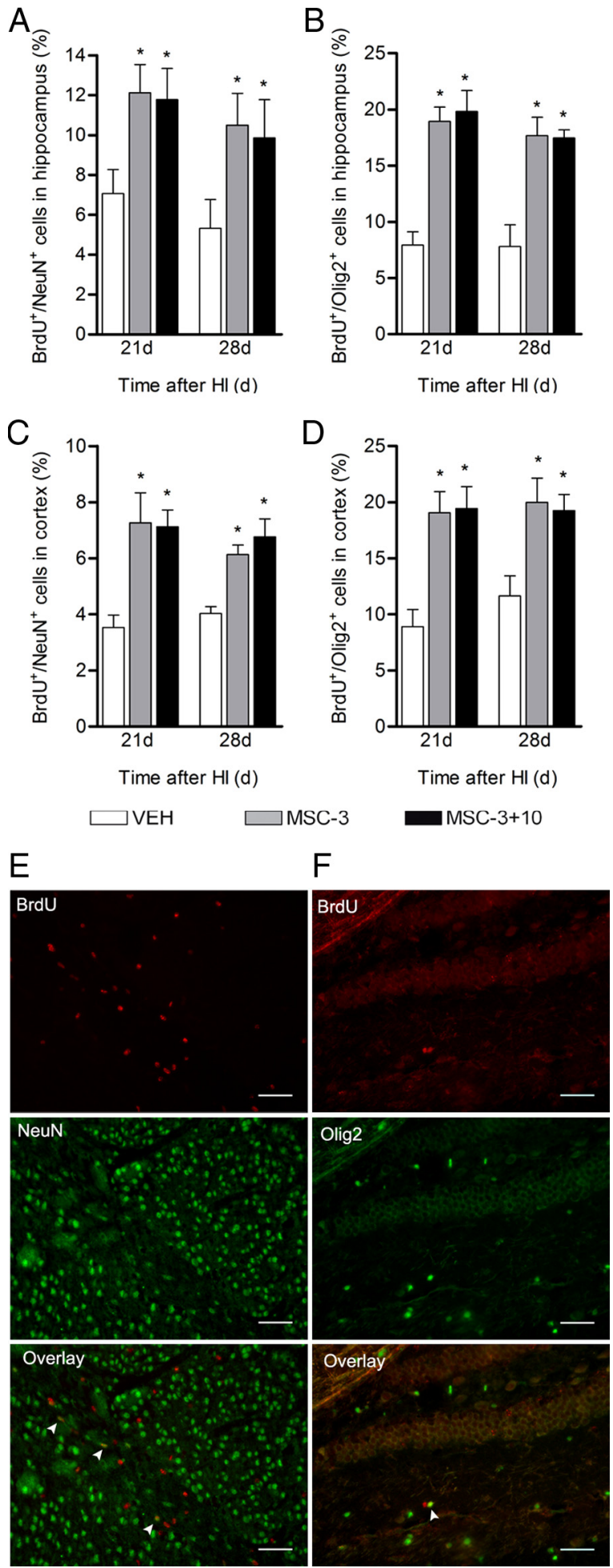

Figure 4. Differentiation of recently divided cells after MSC treatment. $\boldsymbol{A}-\boldsymbol{D}, \mathrm{BrdU}^{+}$cells were analyzed for coexpression of the neuronal marker $\operatorname{NeuN}(\boldsymbol{A}, \boldsymbol{B})$ or the oligodendrocyte precursor marker Olig2 $(\boldsymbol{C}, \boldsymbol{D})$ in hippocampus $(\boldsymbol{A}, \boldsymbol{B})$ and cortex $(\boldsymbol{C}, \boldsymbol{D})$. Data represent mean percentage of double positive cells \pm SEM. VEH, $n=12$; MSC -3 and MSC $-3+10, n=14 .{ }^{*} p<$ 0.05. $\boldsymbol{E}, \boldsymbol{F}$, Representative examples of BrdU-, NeuN- $(\boldsymbol{E})$, or Olig2- $(\boldsymbol{F})$, and double-positive cells at day 28 after MSC-3 treatment. Scale bars, $50 \mu \mathrm{m}$.

HI when compared with VEH animals. However, we observed no additional increase in the percentage of double-positive cells after the second injection with MSCs at $10 \mathrm{~d}$ in comparison with MSC-3treated mice. 
A

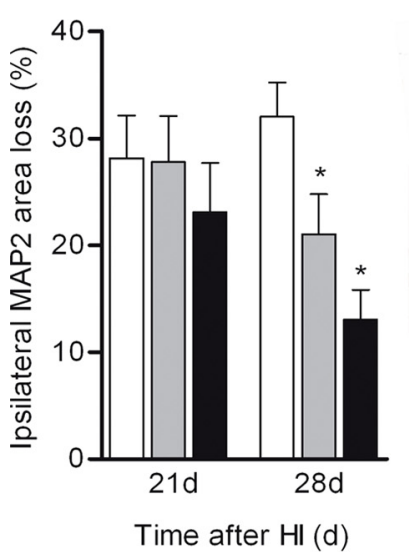

B

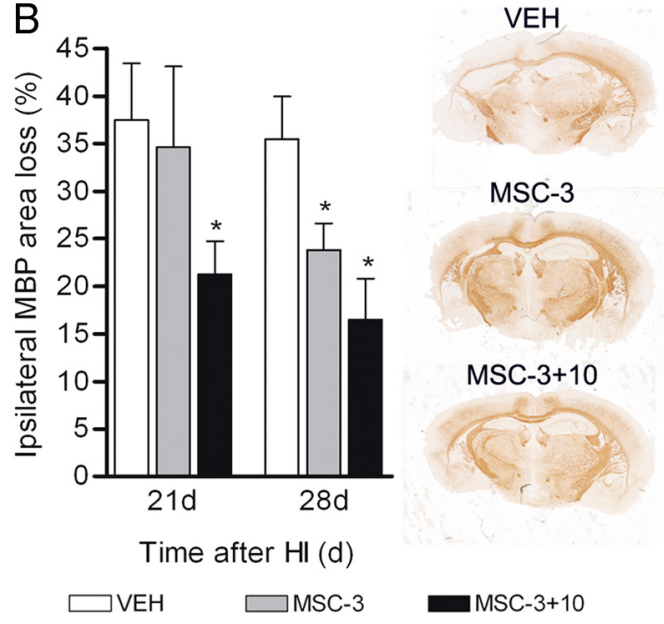

Figure 5. $\quad A, B$, Effect of treatment with MSCS on lesion size. Quantification of $\mathrm{MAP2}^{+}(\boldsymbol{A})$ and $\mathrm{MBP}^{+}(\boldsymbol{B})$ area loss expressed as ratio ipsilateral/contralateral area and representative examples of MAP2 or MBP staining at day 28 after $\mathrm{HI}$. Data represent mean percentage area loss \pm SEM. VEH, $n=12$; MSC- 3 and MSC $-3+10, n=14 .{ }^{*} p<0.05$.

Since no increase in EDU-positive cells was observed after the second injection, we could not further determine the effect of the second injection of MSCs on formation of new neurons or oligodendrocytes.

\section{Effect of MSC treatment on brain damage}

We analyzed loss of ipsilateral MAP2 staining as a measure of neuronal damage or gray matter injury and loss of ipsilateral MBP staining as a measure of oligodendrocyte loss or white matter injury at 21 and $28 \mathrm{~d}$ after the insult. At $21 \mathrm{~d}$ after $\mathrm{HI}$, we observed no effect of MSC-3+10 treatment on MAP2 loss. However, at $28 \mathrm{~d}$ after $\mathrm{HI}$, there was a decrease in loss of MAP2 ${ }^{+}$cells with $60 \pm 12.5 \%(p<0.01)$ after MSC treatment when compared with VEH animals. MSC-3 treatment was significantly less powerful with respect to MAP2 loss than MSC-3+10 treatment $(34 \pm 6 \%$ reduction of MAP2 loss; $p<0.05$ ) (Fig. $5 A$ ). At $21 \mathrm{~d}$ after $\mathrm{HI}$, there was a decrease in the loss of $\mathrm{MBP}^{+}$cells with $36 \pm$ $6 \%(p<0.01)$ in MSC-3+10 animals compared with VEH animals. At this early time point, MSC-3 treatment did not influence MBP staining. At $28 \mathrm{~d}$ after HI, MBP loss was significantly decreased in both MSC-3+ 10 (53 $\pm 13 \% ; p<0.01)$ - and MSC-3 $(33 \pm 4 \% ; p<0.05)$-treated groups. Moreover, the effect of MSC-3 +10 treatment was significantly larger than that of MSC-3 treatment $(p<0.05)$ (Fig. $5 B)$.
Corticospinal tract remodeling after neonatal HI and MSCs

We observed marked improvement in sensorimotor function by MSC-3+10 treatment, and we therefore hypothesized that the second MSC treatment might stimulate axonal remodeling and growth. In our model of HI brain damage, we do not have evidence for extensive neuronal loss in the ipsilateral motor cortex (Fig. 6A). Therefore, we hypothesized that impaired functioning of the corticospinal tract (e.g., because of damage to long tracts) (Weidner et al., 2001) may underlie the impaired motor function we observed. To visualize the effect of MSC-3+10 treatment on the functional activity of the CST, animals were injected with BDA in the ipsilateral motor cortex at $21 \mathrm{~d}$ after HI. Cervical spinal cord was analyzed for distribution of BDA 1 week later $(28$ $\mathrm{d}$ after $\mathrm{HI}$ ). In sham-operated animals, we observed the normal projection pattern with clear positive staining in the dorsal funiculus of the contralateral spinal cord (Fig. 6B) (Weidner et al., 2001; Hsu et al., 2006). In VEH HI mice, contralateral spinal cord BDA staining was markedly reduced, indicating decreased CST axon density or activity (Lapash Daniels et al., 2009; Liu et al., 2009). Notably, after MSC-3+10 treatment, we observed a significant increase in BDA staining in the dorsal funiculus of the contralateral spinal cord compared with VEH HI mice (Fig. 6C). However, MSC-3 or MSC-10 treatment did not give a significant increase in BDA staining in the contralateral dorsal funiculus. These data indicate that the second MSC treatment is necessary for effective remodeling of the CST. To determine whether the remodeling of the CST was related to sensorimotor outcome, we analyzed the relationship between BDA intensity in the contralateral spinal cord and paw preference in the cylinder rearing test at $28 \mathrm{~d}$ after HI. We included VEH, MSC-3, and MSC-3+10 animals in this analysis. Interestingly, we observed a clear inverse relationship between contralateral spinal cord BDA-staining intensity and sensorimotor impairment $(r=-0.75 ; p<0.001)$ (Fig. 6D).

As a measure of neuronal plasticity, we also analyzed the effect of MSC treatment on GAP43 staining as a marker for neuritogenesis (Meiri et al., 1998) and on synaptophysin staining as a marker for synaptogenesis (Leclerc et al., 1989). At $21 \mathrm{~d}$ after HI, we did not observe an effect of MSC-3 or MSC-3+10 on ipsilateral GAP43 or synaptophysin staining. At $28 \mathrm{~d}$ after $\mathrm{HI}$, the ipsilateral area of GAP43 (Fig. 6E) and synaptophysin (Fig. 6F) was increased after MSC-3 treatment when compared with VEH animals. Consistent with a stronger effect of MSC-3+10 treatment on axonal remodeling, the increase in GAP43 or synaptophysin staining was more pronounced after MSC-3+10 compared with MSC-3 treatment.

\section{MSC gene expression profile after culture with ischemic} brain extracts

We have shown that a single treatment with MSCs at 3 or at $10 \mathrm{~d}$ (MSC-3 or MSC-10) after HI stimulated endogenous cell proliferation and improved functional outcome. When a second injection with MSCs was given, cell proliferation was not further stimulated. However, in response to the second treatment, functional outcome further improved and functional improvement was directly related to remodeling of the CST.

These findings indicate that the beneficial effects of the first and second MSC treatment are mediated via different pathways. We hypothesized that MSCs respond to signals from the environment into which they are transplanted and adapt the expression of growth and differentiation factors to signals provided by the environment resulting in activation of specific repair pathways. To examine this possibility, MSCs were cultured in conditioned medium containing brain extracts obtained $10 \mathrm{~d}$ after HI from mice treated either with MSCs at $3 \mathrm{~d}$ after $\mathrm{HI}$ or receiving vehicle at $3 \mathrm{~d}$ 
after the insult. Gene expression profiles of the MSCs were examined in pooled samples using three pathway focused PCR arrays. With an arbitrary cutoff of more than twofold change, expression of 29 genes encoding secreted factors differed between MSCs cultured with HI-vehicle brain extracts compared with MSCs cultured with HIMSC brain extracts (Table 1). In addition, 16 genes encoding nonsecreted factors were differentially regulated when comparing MSCs cultured with HI-vehicle versus HIMSC-3 brain extracts (see supplemental Table 1, available at www.jneurosci.org as supplemental material).

To validate PCR array results, we analyzed four upregulated and three downregulated secreted factors by real-time RT-PCR on the individual samples (Fig. $7 A, B)$. The data confirm the results obtained in the PCR array. In response to culture with HI-MSC brain extracts compared with HI-vehicle brain extract, MSCs significantly upregulated IL-10, IL$1 \beta$, Methallothion-3 (MT3), and nerve growth factor (NGF) (Fig. 7A). A significant downregulation was observed for bone morphogenetic protein 2 (BMP2), Inhibin $\beta-\mathrm{B}$ (Inhbb), and transforming growth factor $\beta$-1 (TGF $\beta 1$ ) (Fig. $7 B$ ) when comparing MSCs cultured with HIMSC brain extracts to MSCs cultured with $\mathrm{HI}$ brain extracts treated with vehicle. We also determined the level of the proinflammatory cytokines IL- $1 \beta$, IL- 6 , and IL-10 in the culture supernatant. In response to in vitro culture of MSCs with $\mathrm{HI}+\mathrm{MSC}$ brain extracts, the level of IL$1 \beta$, IL- 6 , and IL- 10 protein in the culture supernatant was increased compared with MSCs cultured with HI+VEH brain extracts (Fig. 7C-E).

\section{Discussion}

We show here that two MSC injections at 3 and $10 \mathrm{~d}$ after neonatal HI markedly improved sensorimotor function 4 weeks after the insult. MSC-3+10 treatment was more powerful in improving functional outcome and in reducing gray and white matter loss than a single MSC injection at $3 \mathrm{~d}$ after $\mathrm{HI}$. Furthermore, only MSC-3+10 treatment induced significant remodeling of the corticospinal tract after neonatal HI. Notably, although the second injection had significant additional effects on sensorimotor function and lesion size, only the first injection of MSCs stimulated formation/survival of new neurons and oligodendrocytes. These findings indicate that the beneficial effects of the first and second MSC treatment are mediated via different pathways.

In line with our data, Yasuhara et al. $(2006,2008)$ showed that both intracranial and intravenous transplantation of bone marrowderived multipotent adult progenitor cells have beneficial effects after neonatal HI. Similarly, Lee et al. (2010) described that a single
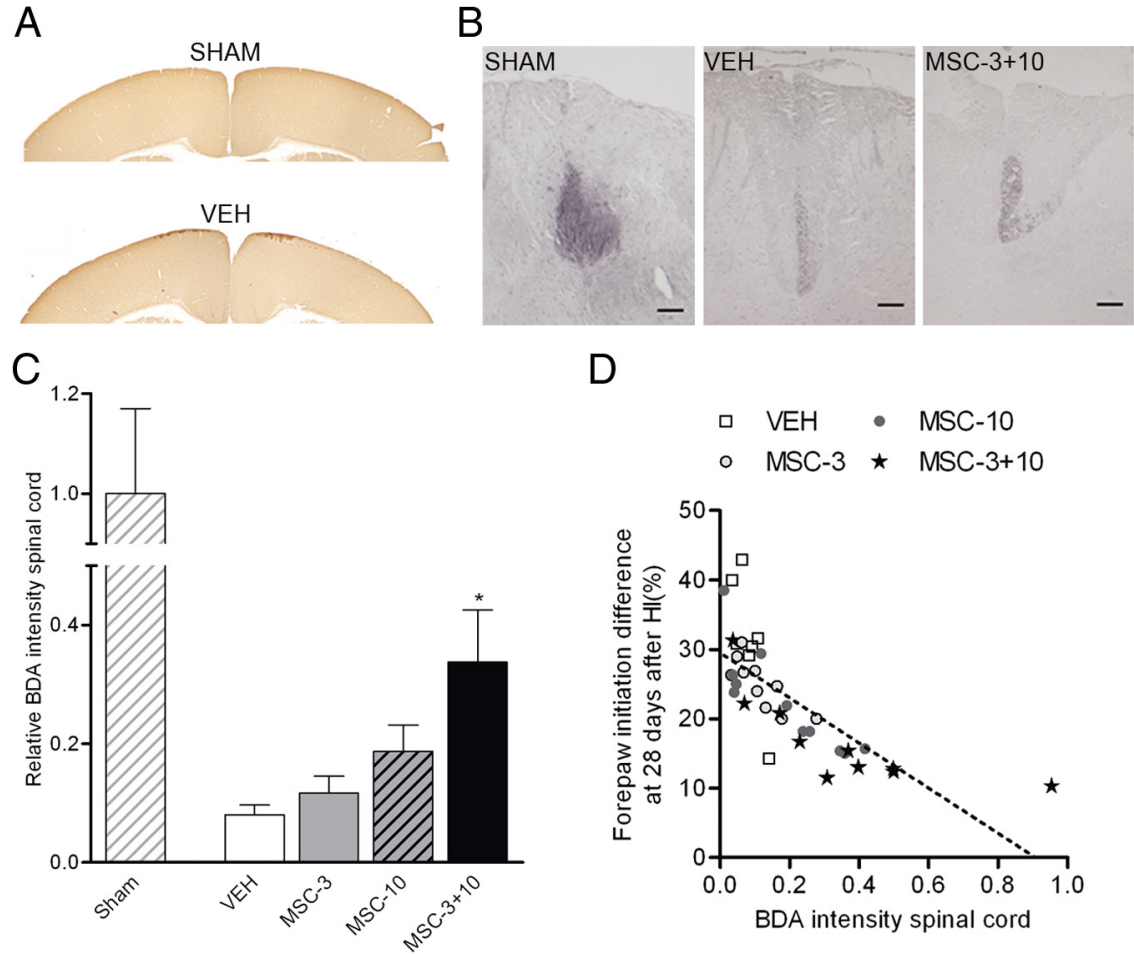

D
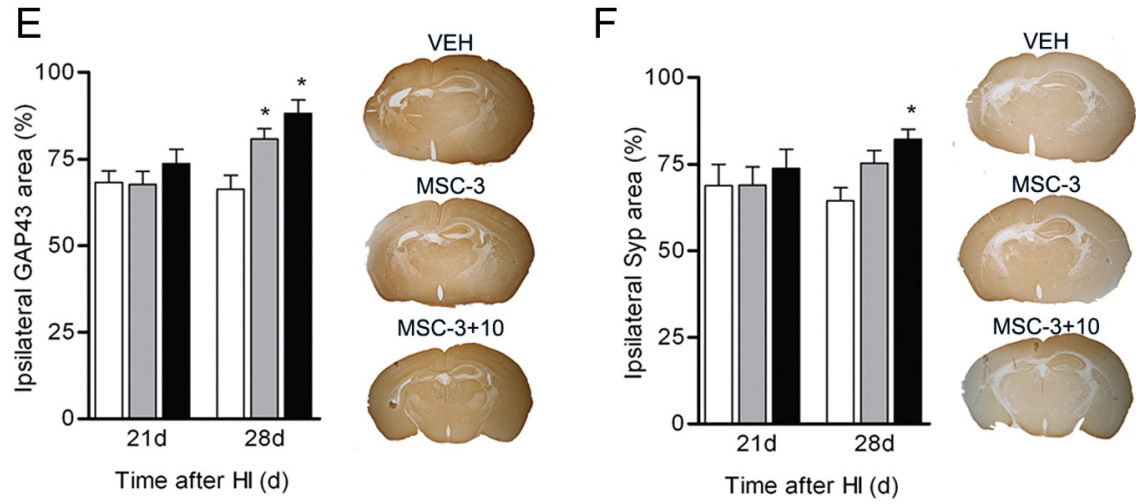

$\square$ VEH

MSC-3

MSC-3+10

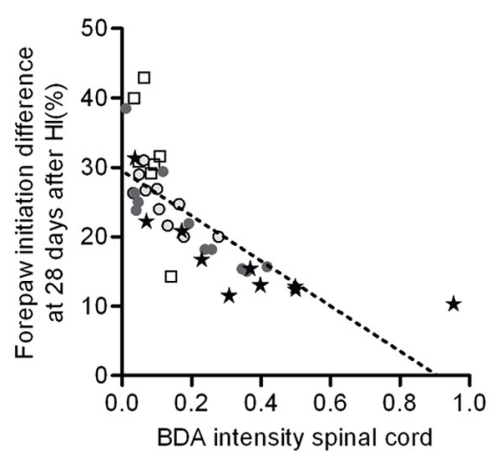

Figure 6. Corticospinal tract remodeling after treatment with MSCS. Mice received VEH, MSC -3 , or MSC $-3+10$ treatment and at $21 \mathrm{~d}$ after $\mathrm{HI}$ were injected with 10k biotinylated dextran amine in the ipsilateral motor cortex. $A$, Analysis of MAP2 staining of the motor cortex at $28 \mathrm{~d}$ after $\mathrm{HI}$ did not reveal any signs of damage. $\boldsymbol{B}$ displays representative examples of BDA staining in the dorsa funiculus of the spinal cord. Scale bar, $20 \mu \mathrm{m}$. C, Relative BDA intensity in the dorsal funiculus of the contralateral cervical spinal cord. Sham controls, $n=7$; VEH, $n=7$; MSC-3, $n=10$; MSC-10, $n=11$; MSC-3+10, $n=10$. ${ }^{*} p<0.05$. D, Relationship between BDA intensity in the dorsal funiculus of the contralateral cervical spinal cord and performance in the cylinder rearing test at $28 \mathrm{~d}$ after HI. VEH, $n=7$; MSC-3, $n=10$; MSC-10, $n=11$; MSC-3+10, $n=10 . r=-0.75$; ${ }^{*} p<0.001$. E, F, Quantification of ipsilateral $\mathrm{GAP}_{3}{ }^{+}(\boldsymbol{E})$ and synaptophysin ${ }^{+}(\boldsymbol{F})$ area expressed as ratio of ipsilateral/contralateral area and representative examples of GAP43 and synaptophysin staining at day 28 after HI. Data represent mean ipsilateral area \pm SEM. Sham controls, $n=7$; VEH, $n=12$; MSC-3, $n=14$; MSC-10, $n=11$; MSC- $3+10, n=13 .{ }^{*} p<0.05$.

intracardial transplantation of MSCs $3 \mathrm{~d}$ after $\mathrm{HI}$ in the neonatal rat also improved contralateral forepaw use. Lesion size was not reduced in that study, which may be attributable to the different route of MSC administration compared with our study.

It has been suggested that MSC treatment decreases brain damage by inhibiting injurious processes, by replacing lost tissue, and/or by enhancing endogenous repair processes (Li et al., 2002, 2005; Chen et al., 2003; Deng et al., 2006; Ohtaki et al., 2008; van Velthoven et al., 2009; Zhang and Chopp, 2009). We detected only very few green fluorescent protein (GFP)-positive cells or GFP/BrdU-positive cells indicative of transplant origin at $28 \mathrm{~d}$ 
Table 1. Gene expression profile of MSCs after culture with HI brain extracts treated with vehicle or MSCs at $3 \mathrm{~d}$ after HI

\begin{tabular}{|c|c|c|c|c|c|}
\hline \multirow[b]{2}{*}{ RefSeq } & \multirow[b]{2}{*}{ Symbol } & \multirow[b]{2}{*}{ Description } & \multicolumn{2}{|l|}{$2^{\wedge}-\Delta \mathrm{Ct}$} & \multirow{2}{*}{$\begin{array}{l}\text { Fold upregulation or downregulation } \\
\mathrm{HI}+\mathrm{MSC} / \mathrm{HI}+\mathrm{VEH} \text { extract }\end{array}$} \\
\hline & & & $\mathrm{HI}+\mathrm{VEH}$ extract & $\mathrm{HI}+\mathrm{MSC}$ extract & \\
\hline NM_009696 & Apoe & Apolipoprotein E & $1.28 \mathrm{E}+01$ & $3.02 \mathrm{E}+01$ & 2.36 \\
\hline NM_009711 & Artn & Artemin & $2.85 \mathrm{E}-04$ & $1.12 \mathrm{E}-03$ & 3.95 \\
\hline NM_007540 & Bdnf & Brain-derived neurotrophic factor & $1.66 \mathrm{E}-03$ & 3.64E-04 & -4.57 \\
\hline NM_009755 & Bmp1 & Bone morphogenetic protein 1 & $6.15 \mathrm{E}-02$ & $2.53 \mathrm{E}-02$ & -2.43 \\
\hline NM_007553 & Bmp2 & Bone morphogenetic protein 2 & $3.41 E-03$ & $6.13 \mathrm{E}-04$ & -5.57 \\
\hline NM_009971 & Csf3 & Colony-stimulating factor 3 (granulocyte) & 2.63E-04 & $1.00 \mathrm{E}-03$ & 3.81 \\
\hline NM_008176 & Cxcl1 & Chemokine (C-X-C motif) ligand 1 & 1.49E-03 & 4.85E-03 & 3.26 \\
\hline NM_021704 & $\mathrm{CxCl} 12$ & Chemokine (C-X-C motif) ligand 12 & $4.50 \mathrm{E}-02$ & $2.14 \mathrm{E}-02$ & -2.10 \\
\hline NM_007950 & Ereg & Epiregulin & 2.45E-03 & $6.41 \mathrm{E}-03$ & 2.62 \\
\hline NM_010198 & Fgf11 & Fibroblast growth factor 11 & $1.04 \mathrm{E}-03$ & 4.03E-04 & -2.59 \\
\hline NM_010200 & Fgf13 & Fibroblast growth factor 13 & 4.14E-03 & $1.55 \mathrm{E}-03$ & -2.67 \\
\hline NM_008006 & Fgf2 & Fibroblast growth factor 2 & 4.07E-03 & $1.65 \mathrm{E}-03$ & -2.47 \\
\hline NM_010216 & Figf & c-fos-induced growth factor & 1.15E-03 & $3.16 \mathrm{E}-04$ & -3.64 \\
\hline NM_010275 & Gdnf & Glial cell line-derived neurotrophic factor & 1.77E-03 & 4.83E-04 & -3.66 \\
\hline NM_010548 & $\| 10$ & IL-10 & 2.84E-03 & $1.73 \mathrm{E}-02$ & 6.09 \\
\hline NM_010554 & $\| 1 \mathrm{a}$ & IL-1 $\alpha$ & $3.90 \mathrm{E}-03$ & $1.84 \mathrm{E}-02$ & 4.72 \\
\hline NM_008361 & $\| 1 b$ & $\mathrm{IL}-1 \beta$ & 7.81E-04 & $6.99 \mathrm{E}-03$ & 8.95 \\
\hline NM_031168 & $\| 6$ & IL-6 & $2.82 \mathrm{E}-04$ & 8.89E-04 & 3.16 \\
\hline NM_008381 & Inhbb & Inhibin $\beta-B$ & $5.55 E-03$ & $3.63 \mathrm{E}-04$ & -15.26 \\
\hline NM_013603 & $\mathrm{Mt3}$ & Metallothionein 3 & $1.68 \mathrm{E}-03$ & 7.17E-03 & 4.28 \\
\hline NM_013609 & Ngf & Nerve growth factor & $6.82 \mathrm{E}-03$ & 4.01E-02 & 5.89 \\
\hline NM_008742 & $\mathrm{Ntf3}$ & Neurotrophin 3 & $2.82 \mathrm{E}-04$ & 7.76E-04 & 2.76 \\
\hline NM_198190 & Ntf5 & Neurotrophin 5 & 2.82E-04 & $6.29 \mathrm{E}-04$ & 2.23 \\
\hline NM_011577 & Tgfb1 & Transforming growth factor, $\beta 1$ & $5.45 \mathrm{E}-01$ & $1.37 \mathrm{E}-01$ & -3.96 \\
\hline NM_009367 & Tgfb2 & Transforming growth factor, $\beta 2$ & $6.97 \mathrm{E}-03$ & $1.74 \mathrm{E}-03$ & -4.01 \\
\hline NM_009368 & Tgfb3 & Transforming growth factor, $\beta 3$ & 8.64E-03 & $3.73 \mathrm{E}-03$ & -2.32 \\
\hline NM_009505 & Vegfa & Vascular endothelial growth factor A & $1.39 \mathrm{E}-02$ & $3.31 \mathrm{E}-02$ & 2.37 \\
\hline NM_011697 & Vegfb & Vascular endothelial growth factor B & 4.32E-02 & $2.14 \mathrm{E}-02$ & -2.02 \\
\hline NM_053009 & Zfp91 & Zinc finger protein 91 & $1.42 \mathrm{E}-03$ & $3.56 \mathrm{E}-03$ & 2.50 \\
\hline
\end{tabular}

Gene expression profiles were examined using three pathway-focused PCR arrays. The table shows secreted factors from which expression differed between MSCs cultured in $\mathrm{HI}+\mathrm{MSC}$ brain extract and $\mathrm{HI}+$ vehicle brain extract.

after HI (data not shown). Thus, our findings do not support previous suggestions that differentiation of transplanted MSCs into neurons and oligodendrocytes restores damage (Mezey et al., 2000; Deng et al., 2006). However, MSC treatment at $3 \mathrm{~d}$ after HI resulted in enhanced endogenous cell proliferation/survival and differentiation of recently divided cells toward NeuN- and Olig2positive cells. These data indicate that MSC-3 treatment stimulates endogenous cell proliferation/survival and differentiation. In addition, inhibition of injurious processes may also contribute to the beneficial effects of MSC treatment (Chen et al., 2003; Li et al., 2005; Ohtaki et al., 2008).

The second injection of MSCs at $10 \mathrm{~d}$ after HI did not increase in cell proliferation/survival, whereas a single injection of MSCs at day 10 did increase cerebral cell proliferation/survival. Although MSC$3+10$ treatment did not further enhance proliferation/survival, it more effectively reduced loss of MAP2 and MBP than a single treatment at $3 \mathrm{~d}$ after HI or at $10 \mathrm{~d}$ after HI (van Velthoven et al., 2010). Together, our data indicate that MSC-3+10 treatment improved function and reduced damage via two complementary processes (i.e., increased formation of new neurons and oligodendrocytes after the first gift, and increased MBP formation indicative of oligodendrocyte maturation and remyelination as well as increased MAP2 staining indicative for neuronal repair without additional enhancement of new cell formation after the second treatment).

The hypothesis that the second MSC treatment stimulated axonal remodeling is supported by the effects we observed on CST activity. Control of voluntary forelimb movement is mediated via the CST and damage to the CST is associated with motor impairment (Iwaniuk and Whishaw, 2000; Liu et al., 2009). Ischemic stroke in adult mice damages the motor cortex affecting the use of the contralesional forelimb, from which animals can recover partially by contralesional CST remodeling (Liu et al., 2009). In the neonatal HI model, we have no evidence for major damage in the ipsilateral motor cortex. Nevertheless, HI brain damage impairs contralateral forelimb use markedly (Chang et al., 2005; van der Kooij et al., 2010). Therefore, we hypothesized that reduced activity of the CST because of damage to long tracts contributed to sensorimotor impairment. Indeed, we show that neonatal HI significantly reduced BDA labeling of the dorsal funiculus of the contralateral cervical spinal cord after BDA injection into the ipsilateral motor cortex. Importantly, BDA labeling in the contralateral spinal cord of MSC-3+10-treated HI animals was significantly increased compared with VEH-treated HI animals. In contrast, a single MSC injection at either 3 or $10 \mathrm{~d}$ after HI did not significantly alter BDA labeling. In addition, we observed an inverse relationship between sensorimotor impairment and cervical spinal cord BDA staining. Furthermore, MSC-3+10 treatment induced a stronger increase in GAP43 and synaptophysin, markers for axonal outgrowth and synaptogenesis (Leclerc et al., 1989; Meiri et al., 1998), when compared with MSC-3 treatment. Collectively, these data indicate that motor recovery after MSC-3+10 treatment may well be mediated by stimulation of axonal growth and/or remodeling leading to restoration of CST integrity.

We hypothesized that the differential effect of MSC treatment at 3 or 3 and $10 \mathrm{~d}$ was dependent on the response of MSCs to the milieu in the brain. To test this hypothesis, we cultured MSCs with HI brain extracts obtained at $10 \mathrm{~d}$ after $\mathrm{HI}$ from mice treated with vehicle or MSCs at $3 \mathrm{~d}$ after HI. Gene expression analysis showed that previous treatment with MSCs changed the microenvironment in the brain so that MSCs responded by changing expression of several secreted factors that are known to regulate brain cell proliferation, differentiation, and/or maturation. For example, IL-10 mRNA and protein expression by MSCs increased in response to HI+MSC compared with $\mathrm{HI}+\mathrm{VEH}$ brain extracts. In an animal model of multiple sclerosis, administration of neural stem cells overexpressing IL-10 promoted remyelination (Yang et al., 2009). In neonatal brain damage, 
a similar mechanism might be operative since upregulation of IL-10 production by MSCs cultured with HI+MSC brain extracts was associated with increased MBP staining after MSC3 + 10 treatment.

mRNA and protein expression of the proinflammatory cytokines IL- $1 \beta$ and IL- 6 was also increased in MSCs exposed to $\mathrm{HI}+\mathrm{MSC}$ compared with $\mathrm{HI}+\mathrm{VEH}$ brain extracts. The majority of studies suggests that IL- $1 \beta$ aggravates damage induced by ischemia, excitotoxicity, or reactive oxygen species (Relton and Rothwell, 1992; Allan et al., 2005). However, in most studies, the role of IL-1 was examined by administering the IL-1 antagonist IL-1RA early after the insult, when the injurious process was ongoing. When we translate our in vitro findings to the in vivo situation, the increased production of IL- $1 \beta$ takes place after the second MSC injection (i.e., $>10 \mathrm{~d}$ after the insult). It may well be that at this time point proinflammatory effects of IL- $1 \beta$ contribute to differentiation of neurons and oligodendrocytes. Interestingly, both IL- $1 \beta$ and IL- 6 promote neuron survival after excitotoxicity (Hama et al., 1991; Toulmond et al., 1992; Loddick et al., 1998), and IL-1 $\beta$ promotes oligodendrocyte remyelination after excitotoxicity, stimulates neurite outgrowth and nerve regeneration in neuronal cultures, and promotes Schwann cell proliferation (Relton and Rothwell, 1992; Carlson et al., 1999; Mason et al., 2001; Temporin et al., 2008).

Expression of several growth and differentiation factors was increased, whereas others were clearly decreased when comparing MSCs cultured with HI-VEH versus HI-MSC brain extracts. For example, CSF3, NGF, and NT-3 expression was upregulated. Administration of these factors induces neurogenesis and promotes functional recovery after stroke (Shyu et al., 2004; Schneider et al., 2005; Frielingsdorf et al., 2007; Zhang et al., 2008). Expression of TGF $\beta 1$ and BMP 2 was clearly decreased in MSCs cultured with MSC-treated brain extracts. Although these factors can have beneficial effects on regeneration, decreased expression of BMP2 can also be positive by shifting differentiation of progenitor cells from astroglia toward neurons (Nakashima et al., 2001; Zhang et al., 2006; Koike et al., 2007). TGF $\beta 1$ stimulates proliferation of neural progenitors, and production of TGF $\beta$ by MSCs was reduced under conditions in which we no longer observed enhanced cell proliferation in vivo (Ma et al., 2008).

In summary, we showed that MSC-3+10 treatment more efficiently restored sensorimotor function and reduced lesion size compared with MSC-3 treatment without an additional increase in formation of new neurons or oligodendrocytes after the second injection of MSCs. Moreover, MSC-3+ 10 treatment partially restored CST activity, reduced MAP2 and MBP loss, and enhanced GAP43 and synaptophysin staining. We also showed that previous treatment with MSCs alters the effect of brain extracts on the pattern of growth and differentiation factors expressed by MSCs. Therefore, we propose that, in the damaged brain, MSCs adapt to the milieu in the brain by secretion of growth factors that stimulate endogenous formation of new neurons and oligodendrocytes, or enhance oligoden-

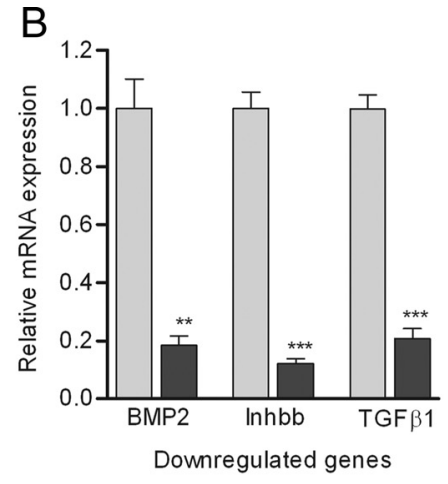

E
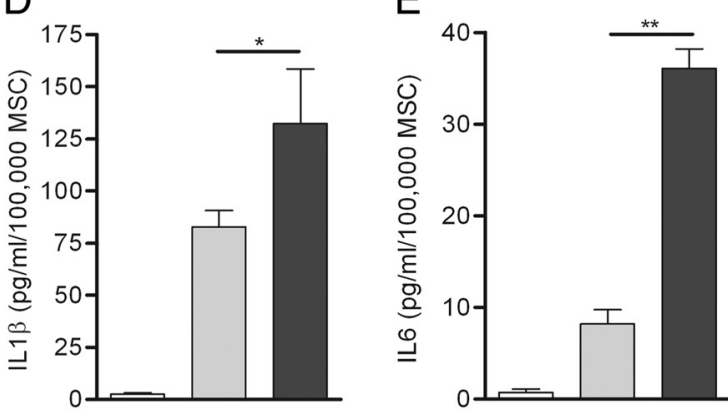

Figure 7. Changes in mRNA levels and protein of selected secreted factors in MSCs cultured with ischemic brain extracts. MSCs downregulated $(\boldsymbol{B})$ genes were quantified by real-time RT-PCR on single samples. $\boldsymbol{C}-\boldsymbol{E}$, The level of IL-10 (C), IL-1 $\beta(\boldsymbol{D})$, and IL-6 $(\boldsymbol{E})$ protein were determined in the culture supernatant. Data represent mean \pm SEM. ${ }^{*} p<0.05 ;{ }^{* *} p<0.001 ;{ }^{* * *} p<0.0001$.

drocyte maturation, and axonal outgrowth and remodeling. Based on our data, we conclude that the efficacy of MSC treatment for restoration of brain integrity and function can be optimized by repeated treatment and will involve mechanisms dependent on the actual milieu in the brain at the time of treatment.

\section{References}

Allan SM, Tyrrell PJ, Rothwell NJ (2005) Interleukin-1 and neuronal injury. Nat Rev Immunol 5:629-640.

Carlson NG, Wieggel WA, Chen J, Bacchi A, Rogers SW, Gahring LC (1999) Inflammatory cytokines IL-1 alpha, IL-1 beta, IL-6, and TNF-alpha impart neuroprotection to an excitotoxin through distinct pathways. J Immunol 163:3963-3968.

Carmichael ST (2006) Cellular and molecular mechanisms of neural repair after stroke: making waves. Ann Neurol 59:735-742.

Chang YS, Mu D, Wendland M, Sheldon RA, Vexler ZS, McQuillen PS, Ferriero DM (2005) Erythropoietin improves functional and histological outcome in neonatal stroke. Pediatr Res 58:106-111.

Chehrehasa F, Meedeniya AC, Dwyer P, Abrahamsen G, Mackay-Sim A (2009) EdU, a new thymidine analogue for labelling proliferating cells in the nervous system. J Neurosci Methods 177:122-130.

Chen J, Li Y, Katakowski M, Chen X, Wang L, Lu D, Lu M, Gautam SC, Chopp M (2003) Intravenous bone marrow stromal cell therapy reduces apoptosis and promotes endogenous cell proliferation after stroke in female rat. J Neurosci Res 73:778-786.

Daadi MM, Davis AS, Arac A, Li Z, Maag AL, Bhatnagar R, Jiang K, Sun G, Wu JC, Steinberg GK (2010) Human neural stem cell grafts modify microglial response and enhance axonal sprouting in neonatal hypoxicischemic brain injury. Stroke 41:516-523.

Deng J, Petersen BE, Steindler DA, Jorgensen ML, Laywell ED (2006) Mesenchymal stem cells spontaneously express neural proteins in culture and are neurogenic after transplantation. Stem Cells 24:1054-1064.

Ferriero DM (2004) Neonatal brain injury. N Engl J Med 351:1985-1995. 
Frielingsdorf H, Simpson DR, Thal LJ, Pizzo DP (2007) Nerve growth factor promotes survival of new neurons in the adult hippocampus. Neurobiol Dis 26:47-55.

Fromm C, Evarts EV (1982) Pyramidal tract neurons in somatosensory cortex: central and peripheral inputs during voluntary movement. Brain Res 238:186-191.

Hama T, Kushima Y, Miyamoto M, Kubota M, Takei N, Hatanaka H (1991) Interleukin-6 improves the survival of mesencephalic catecholaminergic and septal cholinergic neurons from postnatal, two-week-old rats in cultures. Neuroscience 40:445-452.

Hsu JY, Stein SA, Xu XM (2006) Development of the corticospinal tract in the mouse spinal cord: a quantitative ultrastructural analysis. Brain Res 1084:16-27.

Iwaniuk AN, Whishaw IQ (2000) On the origin of skilled forelimb movements. Trends Neurosci 23:372-376.

Koike N, Kassai Y, Kouta Y, Miwa H, Konishi M, Itoh N (2007) Brorin, a novel secreted bone morphogenetic protein antagonist, promotes neurogenesis in mouse neural precursor cells. J Biol Chem 282:15843-15850.

Lapash Daniels CM, Ayers KL, Finley AM, Culver JP, Goldberg MP (2009) Axon sprouting in adult mouse spinal cord after motor cortex stroke. Neurosci Lett 450:191-195.

Leclerc N, Beesley PW, Brown I, Colonnier M, Gurd JW, Paladino T, Hawkes R (1989) Synaptophysin expression during synaptogenesis in the rat cerebellar cortex. J Comp Neurol 280:197-212.

Lee JA, Kim BI, Jo CH, Choi CW, Kim EK, Kim HS, Yoon KS, Choi JH (2010) Mesenchymal stem cell transplantation for hypoxic-ischemic brain injury in neonatal rat model. Pediatr Res 67:42-46.

Li Y, Chen J, Chen XG, Wang L, Gautam SC, Xu YX, Katakowski M, Zhang LJ, Lu M, Janakiraman N, Chopp M (2002) Human marrow stromal cell therapy for stroke in rat: neurotrophins and functional recovery. Neurology 59:514-523.

Li Y, Chen J, Zhang CL, Wang L, Lu D, Katakowski M, Gao Q, Shen LH, Zhang J, Lu M, Chopp M (2005) Gliosis and brain remodeling after treatment of stroke in rats with marrow stromal cells. Glia 49:407-417.

Liu Z, Zhang RL, Li Y, Cui Y, Chopp M (2009) Remodeling of the corticospinal innervation and spontaneous behavioral recovery after ischemic stroke in adult mice. Stroke 40:2546-2551.

Loddick SA, Turnbull AV, Rothwell NJ (1998) Cerebral interleukin-6 is neuroprotective during permanent focal cerebral ischemia in the rat. J Cereb Blood Flow Metab 18:176-179.

Ma M, Ma Y, Yi X, Guo R, Zhu W, Fan X, Xu G, Frey WH 2nd, Liu X (2008) Intranasal delivery of transforming growth factor-betal in mice after stroke reduces infarct volume and increases neurogenesis in the subventricular zone. BMC Neurosci 9:117.

Mason JL, Suzuki K, Chaplin DD, Matsushima GK (2001) Interleukin1beta promotes repair of the CNS. J Neurosci 21:7046-7052.

Meier C, Middelanis J, Wasielewski B, Neuhoff S, Roth-Haerer A, Gantert M, Dinse HR, Dermietzel R, Jensen A (2006) Spastic paresis after perinatal brain damage in rats is reduced by human cord blood mononuclear cells. Pediatr Res 59:244-249.

Meiri KF, Saffell JL, Walsh FS, Doherty P (1998) Neurite outgrowth stimulated by neural cell adhesion molecules requires growth-associated protein-43 (GAP-43) function and is associated with GAP-43 phosphorylation in growth cones. J Neurosci 18:10429-10437.

Mezey E, Chandross KJ, Harta G, Maki RA, McKercher SR (2000) Turning blood into brain: cells bearing neuronal antigens generated in vivo from bone marrow. Science 290:1779-1782.

Nakashima K, Takizawa T, Ochiai W, Yanagisawa M, Hisatsune T, Nakafuku M, Miyazono K, Kishimoto T, Kageyama R, Taga T (2001) BMP2-mediated alteration in the developmental pathway of fetal mouse brain cells from neurogenesis to astrocytogenesis. Proc Natl Acad Sci U S A 98:5868-5873.

Nijboer CH, Kavelaars A, Vroon A, Groenendaal F, van Bel F, Heijnen CJ (2008) Low endogenous G-protein-coupled receptor kinase 2 sensitizes the immature brain to hypoxia-ischemia-induced gray and white matter damage. J Neurosci 28:3324-3332.

Ohtaki H, Ylostalo JH, Foraker JE, Robinson AP, Reger RL, Shioda S, Prockop DJ (2008) Stem/progenitor cells from bone marrow decrease neuronal death in global ischemia by modulation of inflammatory/immune responses. Proc Natl Acad Sci U S A 105:14638-14643.
Pimentel-Coelho PM, Mendez-Otero R (2010) Cell therapy for neonatal hypoxic-ischemic encephalopathy. Stem Cells Dev 19:299-310.

Pimentel-Coelho PM, Magalhães ES, Lopes LM, deAzevedo LC, Santiago MF, Mendez-Otero R (2010) Human cord blood transplantation in a neonatal rat model of hypoxic-ischemic brain damage: functional outcome related to neuroprotection in the striatum. Stem Cells Dev 19:351-358.

Qu R, Li Y, Gao Q, Shen L, Zhang J, Liu Z, Chen X, Chopp M (2007) Neurotrophic and growth factor gene expression profiling of mouse bone marrow stromal cells induced by ischemic brain extracts. Neuropathology 27:355-363.

Relton JK, Rothwell NJ (1992) Interleukin-1 receptor antagonist inhibits ischaemic and excitotoxic neuronal damage in the rat. Brain Res Bull 29:243-246.

Schneider A, Krüger C, Steigleder T, Weber D, Pitzer C, Laage R, Aronowski J, Maurer MH, Gassler N, Mier W, Hasselblatt M, Kollmar R, Schwab S, Sommer C, Bach A, Kuhn HG, Schäbitz WR (2005) The hematopoietic factor G-CSF is a neuronal ligand that counteracts programmed cell death and drives neurogenesis. J Clin Invest 115:2083-2098.

Shen LH, Li Y, Chen J, Cui Y, Zhang C, Kapke A, Lu M, Savant-Bhonsale S, Chopp M (2007) One-year follow-up after bone marrow stromal cell treatment in middle-aged female rats with stroke. Stroke 38:2150-2156.

Shyu WC, Lin SZ, Yang HI, Tzeng YS, Pang CY, Yen PS, Li H (2004) Functional recovery of stroke rats induced by granulocyte colony-stimulating factor-stimulated stem cells. Circulation 110:1847-1854.

Temporin K, Tanaka H, Kuroda Y, Okada K, Yachi K, Moritomo H, Murase T, Yoshikawa H (2008) IL-1beta promotes neurite outgrowth by deactivating RhoA via p38 MAPK pathway. Biochem Biophys Res Commun 365:375-380.

Toulmond S, Vige X, Fage D, Benavides J (1992) Local infusion of interleukin-6 attenuates the neurotoxic effects of NMDA on rat striatal cholinergic neurons. Neurosci Lett 144:49-52.

van der Kooij MA, Ohl F, Arndt SS, Kavelaars A, van Bel F, Heijnen CJ (2010) Mild neonatal hypoxia-ischemia induces long-term motor- and cognitive impairments in mice. Brain Behav Immun 24:850-856.

van Velthoven CT, Kavelaars A, van Bel F, Heijnen CJ (2009) Regeneration of the ischemic brain by engineered stem cells: fuelling endogenous repair processes. Brain Res Rev 61:1-13.

van Velthoven CT, Kavelaars A, van Bel F, Heijnen CJ (2010) Mesenchymal stem cell treatment after neonatal hypoxic-ischemic brain injury improves behavioral outcome and induces neuronal and oligodendrocyte regeneration. Brain Behav Immun 24:387-393.

Volpe JJ (2001) Neurology of the newborn. Philadelphia: Saunders.

Weidner N, Ner A, Salimi N, Tuszynski MH (2001) Spontaneous corticospinal axonal plasticity and functional recovery after adult central nervous system injury. Proc Natl Acad Sci U S A 98:3513-3518.

Yang J, Jiang Z, Fitzgerald DC, Ma C, Yu S, Li H, Zhao Z, Li Y, Ciric B, Curtis M, Rostami A, Zhang GX (2009) Adult neural stem cells expressing IL-10 confer potent immunomodulation and remyelination in experimental autoimmune encephalitis. J Clin Invest 119:3678-3691.

Yasuhara T, Matsukawa N, Yu G, Xu L, Mays RW, Kovach J, Deans RJ, Hess DC, Carroll JE, Borlongan CV (2006) Behavioral and histological characterization of intrahippocampal grafts of human bone marrow-derived multipotent progenitor cells in neonatal rats with hypoxic-ischemic injury. Cell Transplant 15:231-238.

Yasuhara T, Hara K, Maki M, Mays RW, Deans RJ, Hess DC, Carroll JE, Borlongan CV (2008) Intravenous grafts recapitulate the neurorestoration afforded by intracerebrally delivered multipotent adult progenitor cells in neonatal hypoxic-ischemic rats. J Cereb Blood Flow Metab 28:1804-1810.

Zhang C, Li Y, Chen J, Gao Q, Zacharek A, Kapke A, Chopp M (2006) Bone marrow stromal cells upregulate expression of bone morphogenetic proteins 2 and 4, gap junction protein connexin- 43 and synaptophysin after stroke in rats. Neuroscience 141:687-695.

Zhang ZG, Chopp M (2009) Neurorestorative therapies for stroke: underlying mechanisms and translation to the clinic. Lancet Neurol 8:491-500.

Zhang ZH, Wang RZ, Wang RZ, Li GL, Wei JJ, Li ZJ, Feng M, Kang J, Du WC, Ma WB, Li YN, Yang Y, Kong YG (2008) Transplantation of neural stem cells modified by human neurotrophin-3 promotes functional recovery after transient focal cerebral ischemia in rats. Neurosci Lett 444 : 227-230. 